\title{
Analysis of Culture-Specific Items and Translation Strategies Applied in Translating Jalal Al-Ahmad's by the Pen
}

\author{
Shekoufeh Daghoughi ${ }^{1} \&$ Mahmood Hashemian $^{2}$ \\ ${ }^{1}$ Department of Foreign Languages, Isfahan (Khorasgan) Branch, Islamic Azad University, Isfahan, Iran \\ ${ }^{2}$ Shahrekord University, Iran \\ Correspondence: Mahmood Hashemian, Shahrekord University, Iran. E-mail: m72h@yahoo.com
}

Received: January 21, 2016 Accepted: March 18, 2016 Online Published: March 21, 2016

doi: $10.5539 /$ elt.v9n4p171

URL: http://dx.doi.org/10.5539/elt.v9n4p171

\begin{abstract}
Due to differences across languages, meanings and concepts vary across different languages, too. The most obvious points of difference between languages appear in their literature and their culture-specific items (CSIs), which lead to complexities when transferring meanings and concepts from one language into another. To overcome the complexities arisen from the distinction between languages in the process of translation, translation scholars have proposed different strategies. Newmark's proposed taxonomy for translating CSIs is the framework for achieving this study. So, after adopting CSIs with Newmark's (1988) 5 proposed domains of CSIs, we sought to find his proposed translation strategies applied in the English translation of Jalal Al-Ahmad's By the Pen by Ghanoonparvar (1988) and to evaluate the frequency of each in order to determine which strategy could help the most in translating CSIs. To do so, first, both the source language text and its translation were studied; then, the translation strategies applied were found. Having found the strategies as the sources of the data, they were arranged and analyzed. Results showed that functional equivalent was the most frequently used strategy, and modulation and paraphrase were the least frequently used ones. Findings have pedagogical implications for translation students and literary translators.
\end{abstract}

Keywords: Culture-Specific Items (CSIs), equivalence, translation strategy

\section{Introduction}

According to Bassnett (2002), translation deals with a whole set of extralinguistic criteria. Hervey and Higgins (1992) state in the process of translation proper or correct translation, that the translator bridges the cultural gap between monolingual speakers of different languages. The cultural distances between the source text (ST) audience and the target text (TT) audience can produce a fundamental dissimilarity between the effects of the ST and those of the TT. Cultural gap can best be seen in literary translations; literary works, due to their great number of culture-specific items (CSIs), specific values, aesthetic, and expressive features, are more difficult to translate than other kinds of texts. The more a translator is aware of the complexities of the differences between cultures, the better he or she will translate. Therefore, language and culture are closely related to and also inseparable from each other. Nord (1997) refers to Agar's (1991) emphasis on the interdependency of language and culture, stating that Agar views languaculture as a single entity, declaring that the culture boundary is marked by rich points, as the differences in behaviour, which cause the incompatibility of cultures or breakdowns of communication between two communities in contact. When encountering a new language, some things as new lexical items and grammatical forms are easy to learn; by learning them, one can talk to the people of that language. Other things are more difficult and one needs a little effort to bridge the differences from a language to another. However, one also encounters some things that he or she requires to challenge with their difficulty, their complexity, and their inability to fit into the resources he or she uses to make sense out of the world; these the so-called rich points things include lexical items through speech acts up to the notions about the world. Moreover, regarding the indispensability of language and culture Kolawole and Salawu (2008) state that literary translation deals with translating literary language texts which are full of ambiguities, homonyms, and arbitrariness; the lexis and style of each literary author is peculiar to him or her and he or she applies his or her own ideal literary techniques such as figures of speech, proverbs, and homonyms through which he or she makes literary forms. As a result, literary language is highly connotative and subjective. Thus, the more cultural overlap exists between the source and target languages, the less translation problems will be. According to Venuti (2004), 
where two languages are not linguistically and culturally distant, the translators come across the least number of serious problems. Translating CSIs in literary translations is seemingly one of the most challenging tasks to be carried out by a translator because it involves the difficulty of producing well-translated texts, along with being faithful to the message. Larson (1984) defines culture as a collection of beliefs, attitudes, values, and rules among a group of people. The particular culture of the society produces the specific language of that society, and the language, itself, reflects the kind of culture.

To explain the concept of culture and culture-specificity, according to Vermeer (1986, as cited in Nord, 1997), culture is whatever one has to know for how to behave, feel, and act in a society in order to conform to general expectations of that society, unless one is prepared to undertake the consequences of his or her unaccepted behavior. As cited in Nord (1997), in his definition, Vermeer (1986) has emphasized human action and behavior as the dynamic qualities of this definition, conceiving culture as a complex system which determines any human action or behavior, including language. Nord (1997) states that this definition by Vermeer (1986) may be a move toward a descriptive, as well as explicative, or prescriptive approach to culture-specificity. Nord (1997) states that for Vermeer (1987), a culture is the entire setting of norms and conventions which an individual as a member of his society must know in order to be like everybody — or to be able to be different from everybody. According to Vermeer (1990, as cited in Nord, 1997):

Every cultural phenomenon is assigned a position in a complex system of values; it is evaluated. And, every individual is an element in a system of space-time coordinates. If this is accepted, transcultural action or communication across culture barriers has to take account of cultural differences with regard to behavior, evaluation, and communicative situations (p. 33).

Languages encompass plenty of CSIs; however, it is difficult to define exactly what can be classified in a text as culture-specific. According to Aixela (1996), CSIs are, "elements of the text that are connected to certain concepts in the foreign culture (history, art, literature) which might be unknown to the readers of the TT" (p. 14). Therefore, it can be concluded that CSIs result in the existence of an intercultural gap between the SL and the TL. Such a gap is found where an item in the ST does not exist in the TL culture, or the TL has no word for that item. To bridge the cultural gaps between languages and produce a comprehensible translation which mirrors the contents of the original text, translation scholars have proposed different strategies and procedures. Among those who have proposed their strategies for translation, Newmark (1988) first proposes five domains for classifying foreign cultural words. These domains are:

1) Ecology (flora, fauna, winds, plains, hills)

2) Material culture (food, clothes, houses and towns, transport)

3) Social culture (work and leisure)

4) Organizations, customs, activities, procedures, concepts (political and administrative, religious, artistic

5) Gesture and habits

And then, he introduces different strategies for translating CSIs;. Newmark's (1988) taxonomy includes:

- Transference: It is the process of transferring an SL word to a TL text as a translation procedure. It includes transliteration, which relates to the conversion of different alphabets: for example, Russian (Cyrillic), Greek, Arabic, and so on into English. The word, then, becomes a loan word. It includes transliteration and is the same as what is called transcription.

- Naturalization: It conforms the SL word first to the normal pronunciation, then, to the normal morphology of the TL.

- Cultural Equivalent: It intends replacing a cultural word in the SL with an, although not accurate, TL word.

- Functional Equivalent: In this procedure, a culture-free word is used, sometimes a new specific term is used; therefore, it generalizes the SL word.

- Descriptive Equivalent: In this procedure, the meaning of the CBT is explained in several words.

- Componential Analysis: It means comparing an SL word with a TL word which has a similar meaning, although not being its one-to-one equivalent, by presenting, first, their common, and then, their differing sense components.

- Synonymy: It is a near TL equivalent. Here economy trumps accuracy. 
- Through-Translation: It is the literal translation of common collocations, names of organizations and components of compounds. It can also be called: calque or loan translation.

- Shifts or Transpositions: It involves a change in the grammar from SL to TL, e.g., (i) change from singular to plural; (ii) when a specific SL structure does not exist in the TL, a change is required; (iii) change of an SL verb to a TL word, change of an SL noun group to a TL noun, and so forth.

- Modulation: It occurs when the translator reproduces the message of the original text in the TL text in accordance with the current norms of the TL, because, the SL and the TL may be different in perspective.

- Recognized Translation: It occurs when the translator normally uses the official or the generally accepted translation of any institutional term.

- Compensation: It occurs when loss of meaning in one part of a sentence is compensated in another part.

- Paraphrase: In paraphrasing, the meaning of the CBT is explained. The explanation in paraphrasing is much more detailed than in descriptive equivalent.

- Couplets: It occurs when the translator applies two different procedures together.

- Notes, Additions, Glosses: These are additional information which a translator may have to add to his version; the additional information that the translator adds are normally cultural.

The purpose of the present study was to investigate Newmark's (1988) strategies for translating CSIs applied in Jalal Al-Ahmad's By the Pen by Ghanoonparvar (1988) to determine which strategy can help most in the translation of the CSIs to make the ST more comprehensible for the readers of the TT. The translator has employed certain kinds of translation strategies. Therefore, this study started with samples of the theoretical principles of CSIs translation applied by the translator in his translation; then, the data were analyzed and discussed; finally, the success or failure ratios of all procedures were investigated. So, based on what was mentioned above, the following research questions were posed to be answered in this study:

1) Which translation strategies of Newmark's model have been applied in the English translation of Jalal Al-Ahmad's By the Pen by Ghanoonparvar (1988)?

2) What is the frequency of use of each strategy in the translation of Jalal Al-Ahmad's By the Pen by Ghanoonparvar (1988)?

3) Based on the frequency of use, which translation strategy can be regarded as the best and most effective translation strategy in translating culture-specific items in such folklore literary texts as Jalal Al-Ahmad's By the Pen?

\section{Method}

\subsection{Materials}

We chose By the Pen and its English translation by Ghanoonparvar (1988) as the corpus of the study because it is a famous Persian folklore story and the author was - if not the best-one of the best authors of his era. The other reason for choosing this story is that it displays the translation of CSIs, and encompasses a great number of CSIs which can fulfill the requirements of this research and provides valuable sources of the data. Dehkhoda Dictionary (Dehkhoda, 194), Farhang Farsi (Moeen, 2006) and Oxford Learner's Dictionary were used as the sources to find the meanings of the words in Persian and English.

\subsection{Procedure}

The methodology was library research and a descriptive-interpretive analysis of the ST and the TT. Newmark's (1988) classification of CSIs was adopted as the theoretical framework of this study that aimed at carrying out an analysis of the CSIs in By the Pen, detecting and describing strategies proposed by Newmark (1988) to cope with CSIs, and to find the frequency of each. In this study, it was the context which determined the unit of analysis. So, the unit of analysis could be a word, a phrase, or a sentence. The procedure contained the three following phases: (1) starting with reading the ST (i.e., the original literary text) to find the CSIs based on Newmark's (1988) domains for the CSIs (i.e., ecology, material culture, social culture, organizations, customs, activities, procedures, concepts, and gesture and habits), (2) reading the TT (i.e., the translation by Ghanoonparvar, 1988) to find the translation of the CSIs in the TT, and (3) comparing the ST CSIs with their equivalents in the TT to discriminate Newmark's proposed strategies for translating the CSIs. For better understanding, each strategy is defined and illustrated by examples in Tables 1-15: 
Transference includes transliteration and is the same as what is called transcription. The word, then, becomes a loan word.

Table 1. Examples of transference applied in translating CSIs in by the pen by Ghanoonparvar

\begin{tabular}{|c|c|c|}
\hline Strategy & Source Text (Persian) & Target Text (English) \\
\hline \multirow{3}{*}{ Transference } & ا ملا /molla:/ & Mulla \\
\hline & ق قران /qerann/ & Gheran \\
\hline & | ميرزا /mi:rza:/ & Mirza \\
\hline
\end{tabular}

Naturalization conforms the SL word, first to the normal pronunciation, then, to the normal morphology of the TL.

Table 2. Examples of naturalization applied in translating CSIs in by the pen by Ghanoonparvar

\begin{tabular}{|c|c|c|}
\hline Strategy & Source Text (Persian) & Target Text (English) \\
\hline \multirow{4}{*}{ Naturalization } & | وزير/væzi:r/ وز & Vizier \\
\hline & قلندر /qælændær & Calender \\
\hline & ساغرى /sa:qæri:/ & Shagreen \\
\hline & /telesm/ طلسم / & Talisman \\
\hline
\end{tabular}

Cultural equivalent intends replacing a cultural word in the SL with an, although not accurate, TL word.

Table 3. Examples of cultural equivalent applied in translating CSIs in by the pen by Ghanoonparvar

\begin{tabular}{|c|c|c|}
\hline Strategy & Source Text (Persian) & Target Text (English) \\
\hline \multirow[t]{3}{*}{ Cultural Equivalent } & خاله جادرى /xa:le tfa:dəri:/ & Fuddy-duddy \\
\hline & 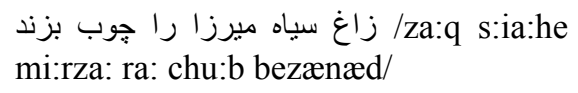 & Keep an eye on Mirza \\
\hline & 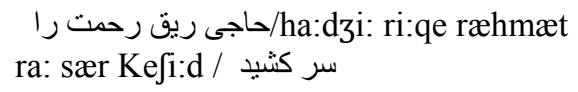 & Haji kicked the bucket \\
\hline
\end{tabular}

In functional equivalent, a culture-free word is used, sometimes a new specific term is used; therefore, it generalizes the SL word.

Table 4. Examples of functional equivalent applied in translating CSIs in by the pen by Ghanoonparvar

\begin{tabular}{|c|c|c|}
\hline Strategy & Source Text (Persian) & Target Text (English) \\
\hline \multirow{3}{*}{ Functional Equivalent } & جشم و هم جشمى /tfefm o hæm tfefmi:/ & To view the other as a competitor \\
\hline & $\begin{array}{l}\text { دم لوله هنگ دار باشى مسجد را ديدن /dæme } \\
\text { lu:lehængda:r ba: } \int \text { ije mæsdzed ra: } \\
\text { di:dæn/ }\end{array}$ & $\begin{array}{l}\text { To grease the palm of the washroom } \\
\text { attendant of the mosque }\end{array}$ \\
\hline & 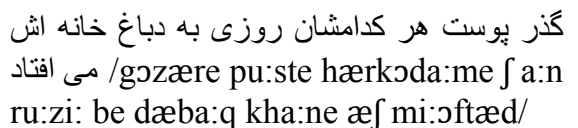 & $\begin{array}{l}\text { They would all be in need of his services } \\
\text { one day }\end{array}$ \\
\hline
\end{tabular}

In descriptive equivalent, the meaning of the culture bound term is explained in several words. 
Table 5. Examples of descriptive equivalent applied in translating CSIs in by the pen by Ghanoonparvar

\begin{tabular}{|c|c|c|}
\hline Strategy & Source Text (Persian) & Target Text (English) \\
\hline \multirow{3}{*}{ Descriptive Equivalent } & / شمع آجين كردن / ل / / a: dzi:n kærdæn a: & To scald with burning candle wax \\
\hline & 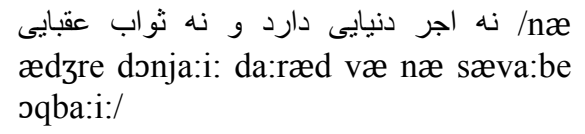 & $\begin{array}{l}\text { Would bring them neither financial gain } \\
\text { in this world nor any reward in the next }\end{array}$ \\
\hline & كرباس /kærba:s/ & Printed cotton cloth \\
\hline
\end{tabular}

Componential analysis means comparing an SL word with a TL word which has a similar meaning, although not being its one-to-one equivalent, by presenting, first, their common, and then, their differing sense components.

Table 6. Examples of componential analysis applied in translating CSIs in by the pen by Ghanoonparvar

\begin{tabular}{lll}
\hline Strategy & Source Text (Persian) & Target Text (English) \\
\hline \multirow{3}{*}{ Componential analysis } & مسجد جامع /mæsdzede dza:me/ & The Grand Mosque \\
& زيلو/zi:lu:/ & Cotton rug \\
& دالان /da:la:n/ & Entrance hall \\
\hline
\end{tabular}

Synonymy is a near TL equivalent.

Table 7. Examples of synonymy applied in translating CSIs in by the pen by Ghanoonparvar

\begin{tabular}{lll}
\hline Strategy & Source Text (Persian) & Target Text (English) \\
\hline \multirow{2}{*}{ Synonymy } & آميرز ابنويس /a:mi:rza: benevi:s/ & Scribe \\
& رمال/mæmaktæ// & Fortune-teller \\
& مكتب خانه xa:ane/ & School \\
\hline
\end{tabular}

Through-translation is the literal translation of common collocations, names of organizations and components of compounds. It can also be called: calque or loan translation.

Table 8. Examples of through-translation applied in translating CSIs in by the pen by Ghanoonparvar

\begin{tabular}{|c|c|c|}
\hline Strategy & Source Text (Persian) & Target Text (English) \\
\hline \multirow{3}{*}{ Through Translation } & / كلم به سر /kælæm be sær/ & Cabbagehead \\
\hline & / صلح نامه / solh na:me/ & Document of conciliation \\
\hline & / وجه ثلث /vædzhe sols/ & Customary one-third \\
\hline
\end{tabular}

Shifts or transpositions involves a change in the grammar from SL to TL.

Table 9. Examples of shift or transposition applied in translating CSIs in by the pen by Ghanoonparvar

\begin{tabular}{|c|c|c|}
\hline Strategy & Source Text (Persian) & Target Text (English) \\
\hline \multirow[t]{3}{*}{ Shift or Transposition } & سين ها /si:n ha:/ & Letter $\sin$ \\
\hline & /pa:rtfeje pi: tfa:zi:e jæzdi:/ & Yazd-made clothing \\
\hline & 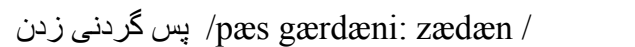 & Pushing and shoving \\
\hline
\end{tabular}

Recognized translation occurs when the translator normally uses the official or the generally accepted translation 
of any institutional term.

Table 10. Examples of recognized translation applied in translating CSIs in by the pen by Ghanoonparvar

\begin{tabular}{|c|c|c|}
\hline Strategy & Source Text (Persian) & Target Text (English) \\
\hline Recognized Translation & ا زنان حرمسر/zæna:ne hæræm særa:/ & Ladies of the harem \\
\hline & $\begin{array}{l}\text { كم كم دكان و دستخاهى به هم زده بودند /kæm } \\
\text { kæm doka:n væ dæstga:hi: be hæm } \\
\text { zæde bu:dænd/ }\end{array}$ & $\begin{array}{l}\text { They had gradually established } \\
\text { themselves as a sort of organization }\end{array}$ \\
\hline
\end{tabular}

Modulation occurs when the translator reproduces the message of the original text in the TL text in accordance with the current norms of the TL, because, the SL and the TL may be different in perspective.

Table 11. Examples of modulation applied in translating CSIs in by the pen by Ghanoonparvar

\begin{tabular}{|c|c|c|}
\hline Strategy & Source Text (Persian) & Target Text (English) \\
\hline Modulation & بخت كثشايى /bæxt gJ J a: i:/ & Good luck \\
\hline
\end{tabular}

In paraphrasing, the meaning of the CBT is explained. The explanation in paraphrasing is much more detailed than in descriptive equivalent.

Table 12. Examples of paraphrase applied in translating CSIs in by the pen by Ghanoonparvar

\begin{tabular}{|c|c|c|}
\hline Strategy & Source Text (Persian) & Target Text (English) \\
\hline Paraphrase & 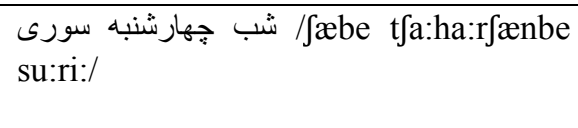 & $\begin{array}{l}\text { The feast of chaharshanbehsuri, which is } \\
\text { celebrated on the eve of the last } \\
\text { Wednesday of the year }\end{array}$ \\
\hline
\end{tabular}

Compensation occurs when loss of meaning in one part of a sentence is compensated in another part.

Table 13. Examples of compensation applied in translating CSIs in by the pen by Ghanoonparvar

\begin{tabular}{|c|c|c|}
\hline Strategy & Source Text (Persian) & Target Text (English) \\
\hline \multirow[t]{2}{*}{ Compensation } & 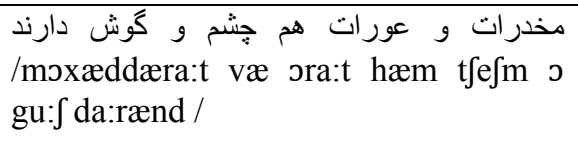 & $\begin{array}{l}\text { The ladies and wives of His Majesty } \\
\text { have eyes and ears }\end{array}$ \\
\hline & حساب سياق /hesa:be si:a:q/ & Siyaq system of accounting \\
\hline
\end{tabular}

Notes, additions, and glosses are additional information which a translator may have to add to his version; the additional information that the translator adds are normally cultural.

Table 14. Examples of note applied in translating CSIs in by the pen by Ghanoonparvar

\begin{tabular}{lll}
\hline Strategy & Source Text (Persian) & Target Text (English) \\
\hline \multirow{3}{*}{ Notes } & عباسى /æbba:si:/ & Abbasi \\
& آقا حروف /a:qa:/ & Aqa \\
& /بجد:fe æbdzæd/ & Abjad letters \\
\hline
\end{tabular}

Couplets occurs when the translator applies two different procedures together. 
Table 15. Examples of couplets applied in translating CSIs in by the pen by Ghanoonparvar

\begin{tabular}{|c|c|c|}
\hline Strategy & Source Text (Persian) & Target Text (English) \\
\hline \multirow{3}{*}{ Couplets } & / اسم اعظم / esme æzæme أم & God's Grand Name \\
\hline & /æbba:si:/ & Abbasi \\
\hline & /qerann/ قران / & Gheran \\
\hline
\end{tabular}

\subsection{Data Analysis}

After categorizing the CSIs according to Newmark's taxonomy and finding their equivalents in the TT, we worked on Newmark's strategies for translating the CSIs applied in By the Pen, including transference, naturalization, cultural equivalent, functional equivalent, descriptive equivalent, componential analysis, synonymy, through-translation, shifts, recognized translation, modulation, paraphrase compensation notes, and couplets. Then, we arranged the data gained in Tables 1-15 in order to shows the cases of applying Newmark's strategies for translating the CSIs. After that, we analyzed the data in Table 16 to represent the frequency of use of each strategy.

\section{Results}

According to the data in Table 16, functional equivalent was the most frequently used strategy in translating the CSIs, and modulation and paraphrase were the least frequently used strategies. Other strategies were synonymy, componential analysis, couplets, notes, through-translation, transference, naturalization, cultural equivalent, descriptive equivalent, shifts, compensation, recognized translation; finally, modulation and paraphrase occupied the same point at the end. For better representation, all of the data obtained are shown in figures in the following section.

Table 16. Frequency and percentage of frequency of each applied strategy

\begin{tabular}{lll}
\hline Translating Strategy & Number of Items Found & Percentage (\%) Based on Total Strategies Used \\
\hline Transference & 50 & 8 \\
Naturalization & 26 & 4.16 \\
Cultural Equivalent & 14 & 2.24 \\
Functional Equivalent & 146 & 23.36 \\
Descriptive Equivalent & 12 & 1.92 \\
Componential Analysis & 99 & 15.84 \\
Synonymy & 115 & 18.4 \\
Through-Translation & 29 & 4.64 \\
Shift or Transposition & 6 & 0.96 \\
Recognized Translation & 2 & 0.32 \\
Compensation & 3 & 0.48 \\
Modulation & 1 & 0.16 \\
Paraphrase & 1 & 0.16 \\
Notes & 60 & 9.6 \\
Couplets & 61 & 9.76 \\
Total & 625 & 100 \\
\hline
\end{tabular}

\subsection{The Most and the Least Frequently Applied Strategies in Figures}

Figure 1 shows the frequency of use of all strategies, and Figure 2 shows the percentage of use of all strategies: 


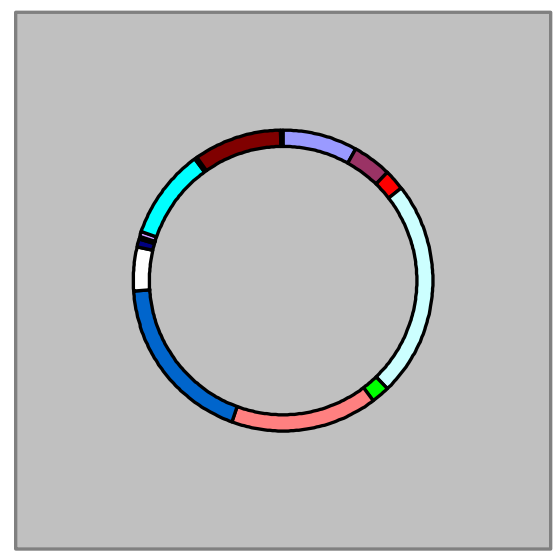

\begin{tabular}{|l|}
\hline$\square$ Transference \\
$\square$ Naturalization \\
$\square$ Cultural equivalent \\
$\square$ Functional equivalent \\
$\square$ Descriptive equivalent \\
$\square$ Componential analysis \\
$\square$ Synonymy \\
$\square$ Through-translation \\
$\square$ Shifts \\
$\square$ Recognized translation \\
$\square$ Compensation \\
$\square$ Couplets \\
$\square$ Modulation \\
$\square$ Notes \\
\end{tabular}

Figure 1. Frequency of use of all strategies applied in translating CSIs in by the pen by Ghanoonparvar

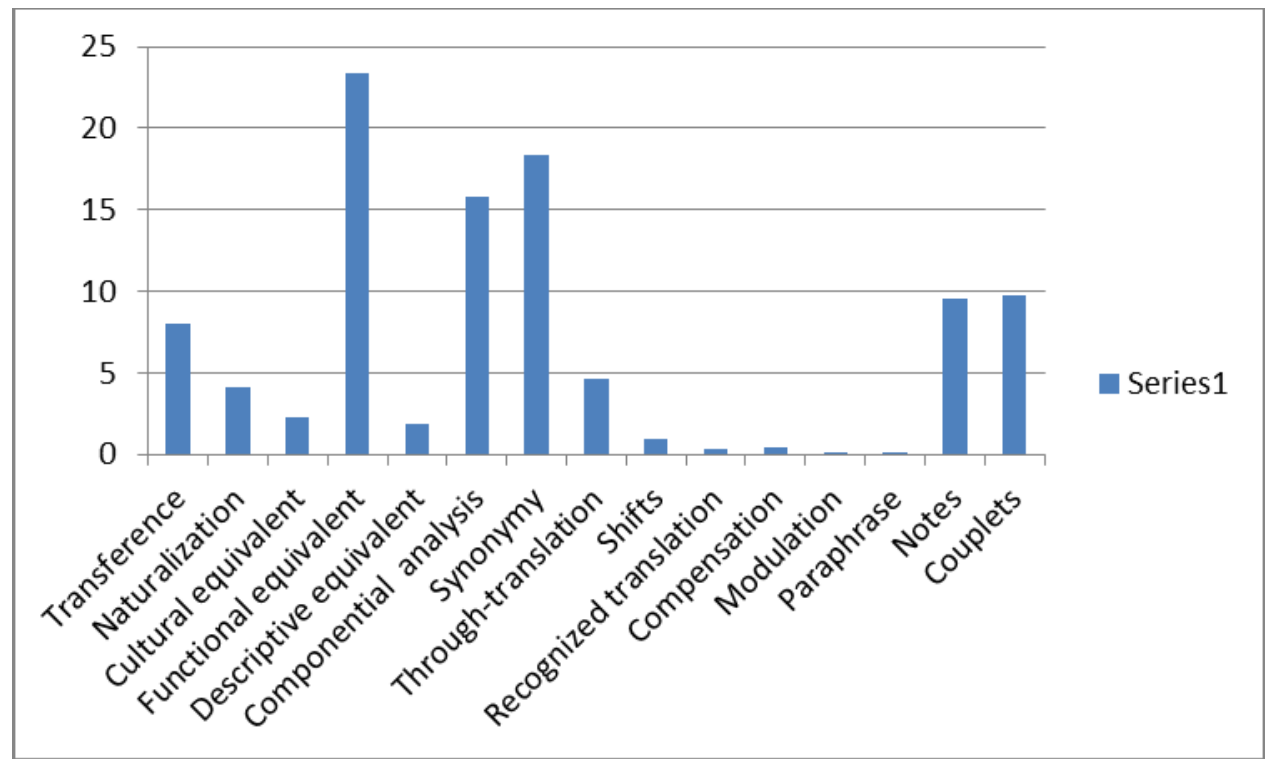

Figure 2. Percentage of use of all strategies applied in translating CSIs in by the pen by Ghanoonparvar

\section{Discussion}

As the results of the study showed, the translator has applied functional equivalent more than other strategies. It shows that the translator has intended to make the SL text more comprehensible to the readers of the TL. Also, in fifty cases, he has applied transference which indicates his respect to the SL culture.

Another point of discussion about the results of this research is that due to the translator's respect for SL culture, he has added some extra information for 60 words at the end of his translation to explain them, so that he could make them understandable for the readers of the TT.

The followings are the points of discussions needed to be made for the use of each of the strategies;

\section{- Transference}

Followings are some of the cases of applying transference. For some words in this text, there are also some extra information in the glossary. These words are as follows:

جهارشنبه سورى /tfa:ha:rfænbe su:ri:/: Chaharshanbehsouri; in addition to the information mentioned in the glossary, the translator has added right after Chaharshanbehsouri in the text, "which is celebrated on the eve of the last Wednesday of the year." In other words, he has applied paraphrase and it seems to be a good idea. 
The words تكيه/tekiə/and حسينيه/hosejniə/ have been translated to Tekke and Hosayniyyeh. These two words have some specific features in Iranian culture. There are some pieces of information in the glossary; however, some extra information should be added at the end of the text or even in the form of footnote.

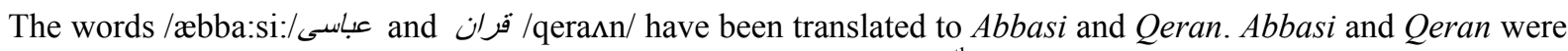
units of money respectively in safavid Shah 'Abbâs and in the $19^{\text {th }}$ century in Iran. The translator has added some information about them in the glossary at the end of the text.

The words آقا /a:qa:/, ميرز/mi:rza:/, سيزان الثريعه /mi:za:nJæri:a/, and ديوان/di:va:n/ have been translated to aqa, Mirza, Seyyed, Mizanoshshari'eh, and Divan. The translator has added some extra information about these words in the glossary. He has used a good technique. This is also true about the translation of the

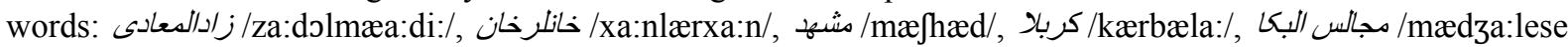

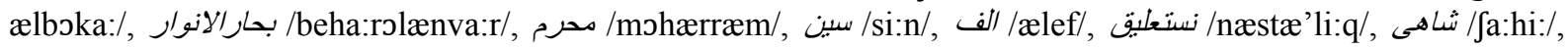

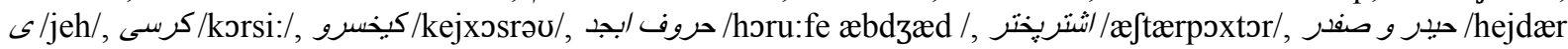

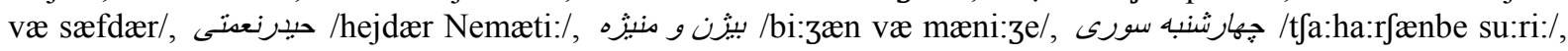

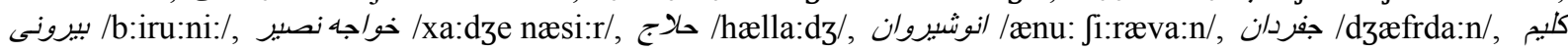
كاشانى /kæli:m Ka:Ja:ni:/, لبلى و مجنون /lejli: væ mædznu:n/.

- Cultural Equivalent

Table 1 contains cases where cultural equivalent has been applied. By the Pen contains lots of informal and cultural words and phrases. For some fourteen cultural items in the ST, there are cultural equivalents in the TL. Some of them are mentioned below:

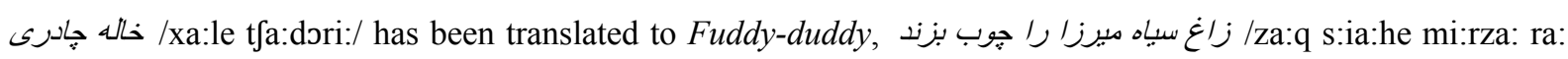
chu:b bezænæd/ has been translated to keep an eye on Mirza, حاجى ريق رحمت را سر كشيد /ha:dzi: ri:qe ræhmæt ra:

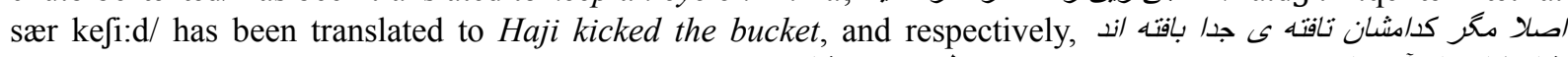

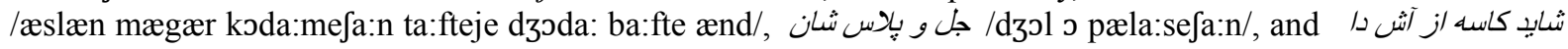

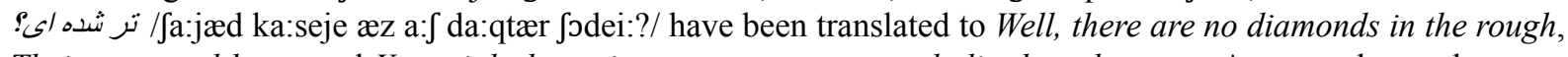
Their rags and bags, and You might be trying to appear more catholic than the pope. As seen above, there are cultural equivalents for the mentioned items.

- Componential Analysis

The phrase مسجد جامع/mæsdzede dza:me/ has been translated to the grand mosque. Congregation mosque could be used instead. But even by translating it to congregation mosque, the strategy used is componential analysis because of not existing any cultural background for دسجد جامع/mæsdzede dza:me/ in the TL. This phrase has a شب شام غريبان /fæbe fa:me qæri:ba:n/ has been translated to: Night of holy prisoners. The translator could not deliver the real meaning of the word properly.

\section{- Synonymy}

The translator has used good equivalents for the words chosen, although, according to the Oxford Learner's Dictionary, for some of the cultural words there are more proper synonyms as the followings;

The word كلانتر/kæla:ntær/ has been translated to: chief constable. The word marshal could be used as a better synonym for this word in the TL. Because, according to the Oxford Learner's Dictionary, marshal is a police officer in certain area or city.

The word داروغه/da:ru:qe/ has been translated to: civil magistrate. The word sheriff could be used as a better equivalent for this word in the TL.

The word بارو/ba:ru:/ has been translated to: wall. The word rampart could be used as a better equivalent for this word in the TL.

The word هارون /tfa:ru:x/ has been translated to: sandal. The word clog seems to be more cultural, and thus, could be used as a better equivalent for this word in the TL.

For once, the word نستعليق/næstæli:q/ has been translated to: polished. This is not a good equivalent for the word بنستعليق Here, the translator was better to apply transference like where he has applied Nasta'liq within the text to respect the SL culture.

The verb تذهبي كردن/tæzhi:b kærdæn/ has been translated to: illustrate. The verb gild could be used as a better synonym for this word in the TL.

The word محرر/mohærrer/ has been translated to: clerk. The word amanuensis seems to convey the meaning 
better in the TL.

The word الغ الغ /Jla:q da:r/ has been translated to: mule driver. The translator was better to use the word mule rider.

The word دباغ خانه /dæbba:q xa:ne/ has been translated to: leather shop. The word tannery could be used as a better synonym for this word in the TL.

The word بى غيرت/bi:qejræt/ has been translated to: good-for-nothing. In the TL, there is another word such as callous that could be used.

For some of the words in the text, the translator has even applied bad equivalents such as هيزى كردن/hi:zi: kærdæn/ has been translated to philandering. Philandering means "having casual sexual relationships with many different women." So, it is not a good equivalent. The verbs gaze and ogle could be used as better equivalents for this word, although the verb ogle conveys the meaning better.

- $\quad$ Shift or Transposition

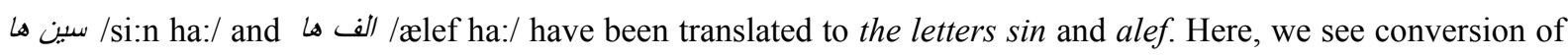
plural to singular.

/da:mæne qæba:/ has been translated to: gown; two words have translated to one word.

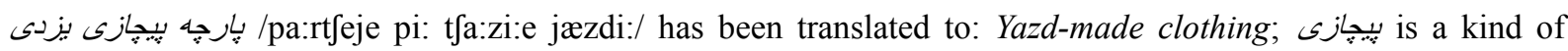
Yazd-made clothing which could have been translated to plaid, although the translator has not used this word.

The verb مقر آمدن /mæqær a:mædæn/ is translated to: confessing. In this case, the use of shift has been obligatory.

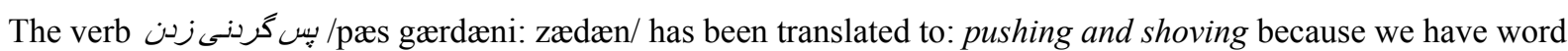
for this feature like slap on the neck, it should not have been applied. And, in the latter case, there is also the case of addition in which the translator has used two different words with almost one meaning; however, because it helps and emphasizes the act, it is not a big problem.

\section{- Recognized Translation}

The translator has used some equivalents which do not resemble the meaning in the SL exactly, but clearly show its meaning in the TL. For example:

كم كم دكان و دستخاهي به هم زده بودند /kæm kæm doka:n væ dæstga:hi: be hæm zæde bu:dænd/ has been translated to: They had gradually established themselves as a sort of organization.

In the above mentioned example, although the translations is dissimilar to its Persian ones, the translator has used the equivalent that is generally accepted by target readers and also shows the meaning clearly.

\section{- Modulation}

There is only one case of applying modulation in this text. The word بخت كثاييى /bæxt gJfa:i:/ has been translated to: good luck. Here, the category of thought is different in the two languages belonging to two totally different cultures, and also the point of view of the ST has been changed in the TT.

\section{- Paraphrase}

There is only one case of applying paraphrase in this text. Due to the importance of جهارشنبه سورى /tfa:ha:rfænbe su:ri:/ in the ST culture, the translator has added "The feast of chaharshanbehsuri, which is celebrated on the eve of the last Wednesday of the year" in the text. Along with paraphrasing this word, the translator has given some notes about Chaharshanbehsouri at the end of the text; in fact, he has intended to explain and introduce Chaharshanbehsouri to the readers of the TT.

\section{- Compensation}

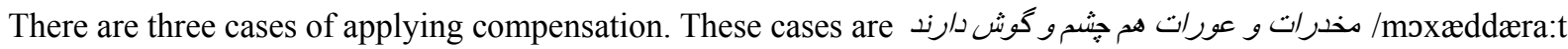

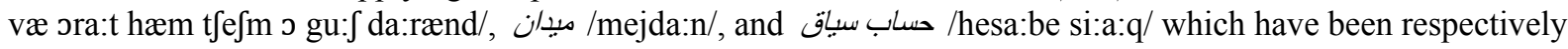
translated to: the ladies and wives of His Majesty have eyes and ears, Farmers market, and Siyaq system of accounting.

\section{Conclusion}

It can be concluded from the data obtained that this translator has used almost all of Newmark's translation strategies for CSIs to render By the Pen successfully. From among Newmark's (1988) list of strategies, functional equivalent was the most frequently used strategy in translating the CSIs in By the Pen by Ghanoonparvar (1988), and modulation and paraphrase were the least frequently used strategies. Considering 
functional equivalent as the most frequently used strategy, other strategies used were synonymy, componential analysis, couplets, notes, through-translation, transference, naturalization, cultural equivalent, descriptive equivalent, shifts, compensation, recognized translation. Finally, modulation and paraphrase together occupied the same point at the end. On the basis of the results, from among Newmark's (1988) strategies, functional equivalent can be considered as the most effective strategy in translating literary folklore texts with a great number of CSIs because it makes such texts comprehensible for the readers of the TT by using English nonculture-specific generally used words and phrases. Moreover, By the Pen is a literary folklore book with a great number of CSIs. Accordingly, the information gained from this study can be helpful for translators, teachers of translation, and translation students in that it will help the improve their ability to translate with special attention to CSIs and will allow them to have a wider view when translating literary texts. Other researchers could also derive similar implications from most of the findings of this research.

\section{References}

Aixela, J. F. (1996). Culture-specific items in translation. In R. Alvarez, \& M. Carmen-Africa Vidal (Eds.), Translation, power, subversion (pp. 52-78). Clevedon: Multilingual Matters.

Bassnett, S. (2002). Translation studies. London: Routledge.

Dehkhoda, A. (1994). Dehkhoda dictionary. Tehran: Amir Kabir.

Ghanoonparvar, M. R. (1988). By the pen. Austin, Texas: Middle East Monographs.

Hervey, S. G. J., \& Higgins, I. (1992). Thinking translation: A course in translation method, French-English. New York: Taylor \& Francis Routledge.

Kolawole, S. O., \& Salawu, A. (2008). The literary translator and the concept of fidelity: Kirkup's translation of CamaraLaye's L'Enfant noir as a case study. Translation Journal, 12(4).

Larson, M. L. (1984). Meaning-based translation: A guide to cross-language equivalence. New York: University Press of America, Inc.

Moeen, M. (2006). Farhang Farsi. Tehran: Iran.

Newmark, P. (1988). A textbook of translation. Hertfordshire: Prentice Hall.

Nord, C. (1997). Translating as a purposeful activity. New York: St. Jerome Publishing.

Oxford Learner's Dictionary (2012). Retrieved August 14, 2015, from $\mathrm{http}: / / \mathrm{www} .0 x$ fordlearnersdictionaries.com/definition/english/

Venuti, L. (Ed.). (2004). The translation studies reader. London and New York: Taylor \& Francis Routledge.

\section{Appendix}

\section{Glossary of Terms}

'Abbâsi: a monetary unit named after safavid Shah 'Abbâs I (ruled 1587-1629), then equivalent to 4.64 grams in silver or gold. By the end of the 19th century, an 'abbâsi equalled two hundred dinars or four shâhis.

Abjad (Ietters): a system of calculation in which every letter of the Arabic alphabet is given a numerical value. For more, see G. Weil and G.S. Colin, “Abdjad," Encyclopaedia of Islam: New Edition 1 (1960): 97-98.

alef: the first of thirty-two letters in the Persian alphabet, which is based on the Arabic alphabet with the addition of four letters.

'Ali (d.660): the cousin and son-in-law of the Moslem Prophet Mohammad (c. 570-632) and the fourth caliph of Islam. More importantly for Iranian Shi'i Moslems, 'Ali is the first of twelve emâms, including his two sons Hasan and Hosayn and the latter's descendants, who are held to have been the legitimate successors to Mohammad. For more see emâm=imam, and H.A.R. Gibb, "Ali b. Abi Talib," Encyclopaedia of Islam: New Edition 1 (1960): 381-386.

“And lo! Those who disbelieve": a Koranic verse, LXVIII: 51.

Anushirvân: Khosrow (Chosroes) I, known as Anushirvan the Just, the famous Sasanian king who ruled from 531-579.

Âqâ : An honorific used to address and refer to males, âqâ is not, however, used as "Mr." can be in English to refer to oneself. âqâ can appear before a surname as in the phrase "âqâ-ye Tehrâni” [Mr. Tehrâni] or after a given name as in "Ahmad âqâ." The second construction is used in addressing servants or working class acquaintances, 
intimate friends, and relatives. By itself, âqâ can mean "Mister" or "Sir" as in "bebakhshid, âqâ" [excuse, me, sir]. In Shi'i Moslem parlance, âqâ can respectfully denote a religious leader.

'Ashurâ: the name of the tenth day of Moharram, the first month in the lslamic lunar calendar. On this day in the year 680 Shi'I Emâm Hosayn and his followers were slain in battle with the forces of the Caliph Yazid on the plains of Karbalâ. For more on the day in general, see P. Marcais, "Ashurâ," Encyclopaedia of Islam: New Edition 1 (1960): 705.

Ashtar Pokhtor: probably a reference to "Eshpokhtor" [inspector], a name given by Iranians to the Russian commander Tesit Sianov at the time of the Russo- Persian wars during the reign of Fath'ali Shâh Qâjâr (ruled 1797-1834).

Azrael: the angel of death and one of four archangels in Islam. When it comes time for a human being to die, a leaf with the person's name on it falls from a tree beneath the throne of Allâh. Azrael (= 'Ezrâil) reads the name and is responsible for separating that person's soul from his/ her body after forty days. For more, see A.J. Wensinck, "Izrâ'il," Encyclopaedia of Islam: New Edition 4(1978): 292-293.

Behârol'anvâr: title of the most famous collection of Shi'i traditions (written 1659-1694), published in a 110-volume edition in Tehrân (1956-1972). Its author is the Safavid theologian and scholar Mollâ Mohammad Bâqer Majlesi (1627-1698), the most influential Shi'i author ever.

Biruni, Abu Rayhân (973-c. 1050): a Persian - speaking scientist and scholar who wrote in Arabic and was a prominent figure in the Ghaznavid court, accompanying Sultan Mahmud on expeditions to India. For more, see D. J. Boilot, “al- Bîrûnî, “ Encyclopaedia of Islam: New Edition 1 (1960): 1236- 1238

Bizhan and Manizheh: legendary lovers immortalized in Ferdowsi’s Shâhnâmeh [Book of Kings]. Their story is presented in Reuben Levy's synoptic prose translation called The Epic of the kings (London: Routledge \& Kegan Paul, 1967), pp. 152-172.

Cabbageheads: reference to shi'i clerics, alluding to the shape of their turbans.

Calender: According to Webster's third International Dictionary of the English Language Unabridged, the word derives from the Persian qalandar and denotes "one of a Sufic order of wandering mendicant dervishes." Qalandar is the word Al-e Ahmad uses in the novel. For more, see "introduction," P. xx.

Chahârshanbeh'suri: a traditional Iranian New Year's gathering on the final Tuesday evening before the beginning of spring, at which people jump over small fires while ritually calling for the fire to draw the (yellow) sallowness of the old year from them and to inspire them with (red) life of the new year. For more, see New Year.

Divân: the collected, nonepic verse of a traditional poet.

Emâm: see Imam.

Ghazal: the most important traditional Persian lyric verse form. Consisting of between four and thirteen or so couplets, the first closed and the others open, with an overall rhyme scheme of aa, ba, ca, da, etc. Love is the basic subject of ghazals, and Hâfez (c. 132.-c. 1390) the most famous ghazal poet in history. Hafez Dance of Life (Washington, D.C: Mage Publishers 1988) provides a multidimensional introduction to Persian ghazals.

God's Grand Name: Among Allâh's many epithets, one is believed to be esm-e a'zam [the grand name], and is a mystery. A Person with the Knowledge of this name is believed to possess great powers of the unknown.

Hâji: the title given to a Moslem male who has made the hajj or holy pilgrimage to Mecca incumbent at least once in a lifetime upon Moslems with the health and means to do so. A woman who makes the hajj is called hâjiyeh. For more on the hijj, see David E. Long, The Hajj Today: A Survey of the Contemporary Makkah Pilgrimage (Albany: SUNY Press, 1979).

Hallâj, Mansur (c.857-922): the famous Arabic-speaking mystic who was tried, convicted, and beheaded in Baghâd by the caliphal authorities for blasphemy, for having reportedly said "Anâ'l- haqq" [I am the creative truth, i.e. God]. For more, see L. Massignon and L. Gardet, "al- Hallâdj,” Encyclopaedia of Islam: New Edition 3 (1971): 99-104.

Haydar and Safdar: titles of the Prophet Mohammad's son- in- law 'Ali. For more, see 'Ali.

Haydaris and Ne'matis: followers of two Sufi leaders Soltân Mir Haydar Tuni (d. 1426/7) and Shâh Ne'matollâh Vali (d. 1431). The proverbial expression "Haydari- Ne'mati quarrel" can refer to any factional conflict, especially hostility rooted in popular religious fanaticism. For more, see Hossein Mirjafari, "The Haydâ̂Ni’matî Conflicts in Iran,” translated and adapted by J.R. Perry, Iranian Studies 12 (1979): 132- 162. 
Hosayniyeh: a term used for shi'i teaching and gathering centers named after the third imam. The most famous was Tehrân's Hosayniyeh- ye Ershâd, where the social reformer 'Ali Shari' ati (1933-1977) lectured from 1967 until his arrest by Pahlavi authorities in 1973 .

Imam: The term denotes, first, a person who stands in front of the ranks of praying Moslems and leads community prayer, In Iran, the term emâm-e jom'eh [Friday imam] is used for a religious leader in any community who leads the Friday community prayer. In Arabic and among the Sunnis, the term is also used to refer to a man learned in Islamic sciences. For Shi'i Moslems, an imam is a hereditary successor to the Prophet Mohammad as leader of the Moslem community. For Twelver Shi'is, there are twelve imams, all considered divinely guided, infallible and sinless, the last of whom is the called "Imam of the Age." For more, see "Imam of the Age" and W. Madelung, "Imâma, Encyclopaedia of Islam: New Edition 3 (1971): 1163-1169.

Imam of the Age: the "Mahdi" or "Hidden Imam," the twelfth Shi'i imam who disappeared in 873 and is expected to remain in occultation until the end of time when he will establish a universal order of justice.

Jafrdân: jafr means "hidden knowledge"; while dân is a verb stem denoting "knowing." Therefore, the surname or title "Jafrdân" means one who possesses esoteric knowledge.

Kalim Kâshâni (d. 1650): a Persian ghazal poet from Hamadân who lived a long while in Kâshân and was named poet laureate in Mughal India during the reign of Shâh Jahân (1628-1659).

Karbalâ: the Iraqi desert site where Hosayn, the younger son of 'Ali and the third Shi'i imam, was killed along with seventy followers by the forces of the Omayyad Caliph Yazid ibn Mu'âwiyah on 10 Moharram $61 \mathrm{AH}$ ( $=680 \mathrm{CE}$ ). For more, see Killing the Imams.

Kaykhosrow: a legendary Iranian King of the Kayâni dynasty treated in Ferdowsi's Shâhnâmeh. The great legendary hero Rostam served Kaykhosrow and other Kayâni monarchs.

Khâjeh Nasiroddin Tusi: see Nasiroddin Tusi.

Khânlar Khân: the name alludes satirically to Parviz Nâtel Khânlari (b. 1913), the Pahlavi-era official, educator, scholar, and literary figure. For more, see "Introduction" above, p. xxi.

Khânom: an honorific for woman denoting "lady," "madam," and the like, it can appear before a surname in contemporary Persian or following a given name.

Killing the imams: a reference to eulogististic accounts of the martyrdoms of the Shi'i imams, especially Hosayn. On dramas about these events, see Peter J. Chelkowski, editor, Ta'ziyeh: Ritual and Drama in Iran (New York: New York University and Sorush Presses, 1979).

Korsi: a traditional heating apparatus consisting of a stool or low table under which a brazier full of glowing crushed charcoal is placed and over which a quilt is stretched, covering the torsos of persons seated around it, cushions at their backs.

Kuchek Khân, Mirzâ: a landowner and liberal intellectual who organized a 1915 meeting in Tehrân to plan social and political reform. His followers were called "Jangali" [forest men], and they fought the Russians and the British in Gilân. Later, as the leader of a separatist movement in Gilân with Bolshevik ties, Kuchek Khân was defeated by Rezâ Khân in 1921. For more, see Richard W. Cottam "Separatist Movements," Nationalism in Iran (Pittsburgh: University of Pittsburgh Press, 1979), PP. 102-106.

Layli and Majnun: legendary Arab lovers. Having lost his heart to Layli, Majnun also loses his mind; his name in Arabic means "crazed." For more on the treatment of the legend in Persian literature, see J.T.P. de Bruijn, “Madjnûn Laylâ,” Encyclopaedia of Islam: New Edition 5 (1986): 1103-1105. Nezâmi's famous verse version of the story is available in a condensed prose translation by R. Gelpke with E. Mattin and G. Hill called The Story of Layla and Majnun (Oxford: Cassirer, 1966).

Majles al-Bokâ: "Gathering of Tears," a traditional compendium of stories for Shi'i mourning.

Man: a variable unit of weight, most commonly equivalent to approximately 3 or 6 kilograms.

Mashhad: The major city in the eastern part of Iran, Mashhad grew as a result of being the burial place of Rezâ, the eighth Shi'i imam, who died there in 818. In fact, the originally Arabic word "Mashhad" means "place where a martyr is buried.

Mashhadi: the title given to a Moslem who has made a pilgrimage to Mashhad to the shrine of the eighth Shi'i imam Rezâ (d. 818) in whose honor a great shrine was built.

Mazdakites: adherents of a religious movement during the later Sasanian Empire (224-640s). It ended with the 
execution of its leader Mazdak and many of his followers in 524.

Mirzâ: an abbreviated form of amirzâdeh [born of a prince] and can denote prince, as in its use in the name Iraj Mirza (1885- 1925), the Qâjâr poet and royal family member. It is also used as an honorific for males and denotes a secretary or scribe, and is used in the novel in this sense.

Mizânoshari'eh: the Congregational prayer leader or imam.

Moharram: the first month of the Islamic lunar calendar year; see 'Ashurâ.

Mohtasham Kâshâni (d. 1587): a Safavid poet best Known for verses commemorating Shi’i imams.

Nasiroddin Tusi, Khâjeh (1201-1274): an astronomer, chronicler, and politician with Shi'i sympathies who served the Mongols. His most famous work is available in English as The Nasirean Ethics, translated by G.M. Wickens (London: Allen \& Unwin, 1964).

Nasta'liq: a cursive calligraphic style used in Persian writing.

New Year: called "Nowruz" [New Day] in Persian , the most traditional and joyous event in the Iranian solar calendar year. It begins on the vernal equinox, March $21^{\text {st }}$ usually, the very first day of spring. New Year's customs include anticipatory spring house cleaning, the purchase of new clothing, presentation of gifts by older to younger family members and of bonuses and special aydi [holiday gratuities] to employees and workers, a ritual New Year's fish and rice dinner, visits to the homes of friends and relatives, and much more. It is an extremely sociable time that officially begins on the last Tuesday evening before the New Year with a traditional gathering called Chahârshanbeh'suri (for more, see Chahârshanbeh' suri). The official end to "Nowruz" celebrations comes on the $13^{\text {th }}$ of Farvardin, the first month in the Iranian solar calendar, when everyone leaves home for a picnic or other outing because staying at home is assumed to bring bad luck. The old year's atmosphere thus leaves the home, and fresh new air will be brought back.

Nezâmolmolk (d. 1092): the famous vizier of the Saljuq Sultan Malekshâh and author of a famous treatise on politics available in English as Book of Government, translated by Hubert Darke (London: Routledge \& Kegan Paul, 1960).

Night of Holy Strangers: the evening of the tenth day of Moharram called "Ashurâ.” For more, see "Ashurâ.

Qalandar: see Calender.

qanât: a "gently sloping tunnel dug horizontally into an alluvial fan until the water table is pierced. Water filters into the tunnel, runs down its gradual slope, and emerges on the surface as a stream." Paul W. English, City and Village in Iran (Madison: University of Wisconsin Press, 1966), p. 30. For a diagram of a typical qanât, see ibid., p. 31.

qerân: or riyâl, one- tenth of a tumân, a basic unit of Iranian currency. In the $19^{\text {th }}$ century, it was a silver coin, equal to one riyâl or 100 dinârs. Today, it is a term still synonymous with riyâl, which is valued officially at \$.07 USA (October 1988).

Rostam: the most famous Iranian hero of legend, the leading heroic figure in Ferdowsi's Shâhnameh [Book of Kings]. Among his many feats was the slaying of the White Demon. Rostam appears in English literature as one of the two protagonists in Matthew Arnold's famous Sohrab and Rustum (1853). The handiest English translation of Ferdowsi's Shâhnâmeh is Reuben Levy's synoptic The Epic of Kings (Chicago: University of Chicago Press, 1967).

Rumi, Jalâloddin (1207-1273): the greatest Sufi poet ever, whose Persian Masnavi-ye Ma'navi [Spiritual Couplets] and Divân (Collected Lyric Poems) are classics of gnostic verse. For more, see Talat S. Halman, "Jalâl al-Din Rumi," Persian Literature, edited by Ehsan Yarshater (Albany: SUNY for Bibliotheca Persica, 1988), pp. 190-213.

Seyyed: The word can mean "sir" or "leader or" leader or refer to the Prophet Mohammad, but is generally used as a title to refer to any descendant of the Prophet.

"Shajan, Shajan": a prayer to ward off evil and mishap.

Shâhi: Literally meaning "Pertaining to the Shâh." The term denotes an Iranian monetary unit in use during the Qâjâr era (1796-1925). In the early twentieth century it was equivalent to fifty dinârs.

Shams-e Tabrizi: "Shams [The Sun] of Tabriz," Rumi's inspirational beloved and guide from 1244 to 1248. For more, see Rumi, the full title of whose Divân is Divân-e Shams-e Tabrizi. A bilingual sampling of those poems appears in Selected Poems from the Dîvân is Divân-e Shams- e Tabrizi, A bilingual sampling of those poems 
appears in Selected poems from the Divân Shamsi Tabrîz, edited and translated by R.A. Nicholson (Cambridge: Cambridge University Press, 1898; reprinted in paperback in 1977).

Shaykh Bahâ'i (1547-1621/2): a scholar- poet with a place of honor at the court of Safavid Shâh 'Abbâs I (ruled 1587-1629). Writing in Persian and Arabic, his best known works are an anthology called al-Kashkul [The Beggar's Bow] and a verse composition in closed couplets called Nân va Halvâ [Bread and Halva].

Shoe storage area: the special location for keeping shoes customarily removed upon entering the prayer hall of a mosque.

Shur and Mahur: two classical Iranian musical modes.

Sin: the fifteenth letter in the Persian alphabet.

Siyâq: an outmoded system of accounting used mostly by bazaar merchants, involving abbreviated symbols based on Arabic numerals.

Sohravardi (1153-1191): a famous Sufi and theologian who was accused of heathenism and strangled in jail. His 'Awârif al-Ma'ârif, available in H. Wilberforce Clarke's Divan-i-Hafiz, 2 volumes (Calcutta and London: 1891), is one of the most popular Sufi treatises.

Tekke: according to Webster's Third International Dictionary of the English Language Unabridged, the term is Turkish and denotes "a dervish monastery." The word "Compound" is used an a synonym.

"There is no god but God": lâ ilâha illâ Allâh: Koran, XLVII: 21, the first part of the profession of faith by which one becomes a Moslem and an utterance often recited in moments of distress or sorrow. Called nafy [negation], this part of the profession is followed by the esbat [affirmation], which goes: wa muhammadun rasâlu allâh [and Mohammad is the Allâh's prophet].

"Those who practice injustice...": Koran, XXVI: 227.

Yeh: the thirty-second and last letter of the Persian alphabet.

Zâd al-Ma'âd: a Persian work by Mohammad Bâqer Majlesi, in which he praises Safavid Soltân Hosayn (ruled 1694- 1722). Majlesi, who practically ruled Iran for several years during Soltân Hosayn's reign held that Shi'is should respect monarchs. For more, see Behârol'anvâr and Abdul Hadi Hairi, "Madilisi, Mulla M.B.," Encyclopaedia of Islam: New Edition 5 (1986): 1086-1088.

\section{Copyrights}

Copyright for this article is retained by the author(s), with first publication rights granted to the journal.

This is an open-access article distributed under the terms and conditions of the Creative Commons Attribution license (http://creativecommons.org/licenses/by/3.0/). 